University of Nebraska - Lincoln

DigitalCommons@University of Nebraska - Lincoln

2012

\title{
Hatching and Fledging Times from Grassland Passerine Nests
}

Pamela J. Pietz

USGS Northern Prairie Wildlife Research Center, ppietz@usgs.gov

D.A. Granfors

U.S. Fish and Wildlife Service, diane_granfors@fws.gov

Todd Grant

U.S. Fish and Wildlife Service, todd_grant@fws.gov

Follow this and additional works at: https://digitalcommons.unl.edu/usgsnpwrc

Part of the Other International and Area Studies Commons

Pietz, Pamela J.; Granfors, D.A.; and Grant, Todd, "Hatching and Fledging Times from Grassland Passerine Nests" (2012). USGS Northern Prairie Wildlife Research Center. 255.

https://digitalcommons.unl.edu/usgsnpwrc/255

This Article is brought to you for free and open access by the US Geological Survey at DigitalCommons@University of Nebraska - Lincoln. It has been accepted for inclusion in USGS Northern Prairie Wildlife Research Center by an authorized administrator of DigitalCommons@University of Nebraska - Lincoln. 


\title{
Hatching and Fledging Times from Grassland Passerine Nests
}

\author{
Pamela J. Pietz, Diane A. Granfors, and Todd A. Grant
}

Abstract. Accurate estimates of fledging age are needed in field studies to avoid inducing premature fledging or missing the fledging event. Both may lead to misinterpretation of nest fate. Correctly assessing nest fate and length of the nestling period can be critical for accurate calculation of nest survival rates. For researchers who mark nestlings, knowing the age at which their activities may cause young to leave nests prematurely could prevent introducing bias to their studies. We estimated fledging ages from grassland passerine nests monitored from hatching through fledging with miniature video cameras in North Dakota and Minnesota during 1996-2001. We compared these values to those obtained from traditional nest visits and from the literature. Mean and modal fledging ages for video-monitored nests were generally similar to those for visited nests, although Clay-colored Sparrows (Spizella pallida) typically fledged 1 day earlier from visited nests. Average fledging ages from both video and nest visits occurred within ranges reported in the literature, but expanded by 1-2 days the upper age limit for Clay-colored Sparrows and the lower age limit for Bobolinks (Dolichonyx oryzivorus). Video showed that eggs hatched throughout the day, whereas most young fledged in the morning (06:30-12:30 CDT). Length of the hatching period for a clutch was usually $>1$ day and was positively correlated with clutch size. Length of the fledging period for a brood was usually $<1$ day, and in nearly half the nests fledging was completed within $<2 \mathrm{hr}$. Video surveillance was a useful tool for obtaining new information and for corroborating published statements related to hatching and fledging chronology. Comparison of data collected from video and nest visits showed that carefully conducted nest visits generally can provide reliable data for deriving estimates of survival.

Key Words: camera, fledging age, grassland, hatching, nest visits, passerine, premature fledging, video. ver 100 years ago, Leon J. Cole presented a report on tagging wild birds in which he suggested that "premature fledging" (Smith 2010:469) was probably the greatest danger to young birds from the work of banders. Banders during that period had discovered that older nestlings sometimes "could not be induced to remain in the nest after they had been removed in the process of banding" and that "in several instances banded young were later found

Pietz, P. I., D. A. Granfors, and T. A. Grant. 2012. Hatching and fledging times from grassland passerine nests. Pp. 47-60 in C. A. Ribic, F. R. Thompson III, and P. J. Pietz (editors). Video surveillance of nesting birds. Studies in Avian Biology (no. 43), University of California Press, Berkeley, CA. 
dead near the nest" (Cole 1910:166). Although recognizing that these deaths were not necessarily a result of banding activities, Cole "called on banders to report which species were more susceptible to premature fledging and at what age nestlings were likely to fledge prematurely" (Smith 2010:469), so they could "govern [their] operations accordingly" (Cole 1910:166).

More recently, the need for better estimates of fledging age has been recognized for other reasons. For example, they are needed to help researchers more accurately assess nest fates of passerines. Nest fates of grassland passerines are typically assessed by repeated nest visits, and investigators typically rely on published estimates of fledging age (e.g., Ehrlich et al. 1988, Poole 2005) to time those visits. Because distinguishing successful nests (i.e., at least one young fledged) from depredated nests can be difficult late in the nestling stage, the timing of such visits can be critical (Pietz et al., chapter 1, this volume). To minimize uncertainty in assigning nest fates, some researchers switch from periodic visits to nests early in the nesting cycle (e.g., every second or third day) to daily visits as the expected fledging date approaches (e.g., Grant et al. 2005). However, data from videomonitored grassland nests have shown that visits at this time can cause young to leave nests earlier than they otherwise would have (i.e., premature fledging), sometimes without the visitor's knowledge (Pietz et al., chapter 1, this volume). Fledging ages published in the literature ostensibly are based on data from observers visiting nests; as such, they may be biased. If an observer, using biased estimates of fledging age, visits a nest earlier than when young would have fledged naturally (i.e., in the absence of external disturbance) and finds the nest empty, he or she might incorrectly conclude that a failed nest had fledged.

The potential for underestimating nest failure can be exacerbated by standard protocol that classifies a nest as successful if, in the absence of other clues, the median date between the last nest check when the nest was active and the nest check when the nest was empty is within 2 days of the predicted fledging date (Martin et al. 1997). As Thompson et al. (1999) noted, using this protocol, nests that are depredated late in the nestling stage likely would be misclassified as successful.
Estimates of fledging age are important for assessing nest fates and also for assigning nest exposure days; both are needed for calculating rates of daily nest mortality, daily nest survival, and period nest survival (e.g., Shaffer 2004). If nest survival is calculated using too few exposure days, but with no bias in number of nests lost, it may lead to an underestimate of survival rates. On the other hand, if nest losses are underestimated, survival rates will likely be overestimated. To help avoid and provide context for these possible biases, we used data collected with video nest surveillance (hereafter video) during our nest predation studies (Pietz et al., chapter 1, this volume) to assess natural fledging ages at successful nests of several species of grassland passerines. We compare data on fledging ages from video to those derived from standard nest visits (using observers) in the same region. We also compare these data to published values of fledging ages for these species.

In the process of extracting data on fledging ages from our video, we also obtained information on (1) the time of day that eggs hatched, (2) the time of day that young fledged, (3) the length of time required for a clutch to hatch (i.e., from first egg to last), and (4) the length of time required for all the young to leave the nest. These data are generally lacking for grassland-nesting passerines, leaving gaps in our basic knowledge of their nesting biology (e.g., Pietz et al., chapter 1, this volume). Many factors can affect these metrics. For example, for a given species, the length of time required to hatch a clutch or fledge a brood likely varies with many interrelated factors: the number of eggs and young in the nest, parental attentiveness, weather, food supply, nestling growth rate, and presence of eggs and young of the parasitic Brown-headed Cowbird (Molothrus ater, hereafter cowbird). Our sample sizes are too limited to assess effects of these potential variables; however, we provide the information we have because such data are scarce, especially for grassland passerines.

The order of information presented in this paper differs by section. For simplicity, in Methods and Results, we order topics by nesting chronology. In the Discussion, as in this introduction, we present issues related to fledging age first because these are most likely to have direct application for field protocols and survival analyses. 


\section{METHODS}

Video-monitored Nests

We obtained video for a sample of passerine nests monitored at grassland sites in southeastern and north-central North Dakota and northwestern Minnesota during 1996-2001. A description of our video system, deployment methods, and methods of nest searching can be found in Pietz and Granfors (2000).

We viewed video from monitored nests to obtain hatching and fledging information. We defined the time of hatch (Central Daylight Time; all times given in CDT) for an individual nestling as the time it was free of the eggshell, or the time an adult removed the eggshell (with or without eating it). In most cases, hatchlings remained attached to eggshells until shells were removed by an adult. Time of fledging was recorded as the time a nestling left a nest and did not return. Young sometimes left nests and returned within minutes; because individuals were not marked, we assumed a returning bird was the same individual that had just left. Grassland passerine young occasionally return to nests a day or more after their initial departure (L. D. Igl, pers. comm.), but we usually removed cameras when the nest was first empty, which precluded us from estimating the frequency of such events.

We used the hatch times of individual eggs and the fledge times of individual young to estimate the time of day most hatching and fledging events occurred (pooled across nests), the length of the hatching period for each nest (amount of time from first egg hatched to last egg hatched, excluding nests from which only one egg hatched), and the length of the fledging period for each nest (amount of time from first young fledged to last young fledged, excluding nests with only one fledgling). Because we were interested in unbiased estimates of fledging age and length of the fledging period, we excluded nests from these calculations if departures from the nest appeared to be precipitated prematurely (e.g., concurrent with observer or predator visits or a nest tipping over); we considered these young to be force fledged (sensu Pietz et al., chapter 1, this volume). Using the same rationale, we also excluded nests with cowbird eggs or young from calculations of host species' hatching or fledging metrics, respectively. We considered parasitized nests separately.
To calculate fledging ages, we included only nests for which entire hatching and fledging periods both had been videotaped. For each nest, we calculated the mean fledging age as the mean fledge date for young in that nest minus the mean hatch date for eggs in that nest. For each species, we calculated the mean fledging age and the associated standard error (SE) from the mean fledging ages for individual nests of that species. For each nest, we calculated the modal fledging age as the modal fledge date for young in that nest minus the modal hatch date for eggs in that nest. As the modal fledging age for each species, we identified the most frequently occurring modal fledging age among the nests of that species (i.e., the mode of the modes).

We used Pearson's $r$ to examine the relationships between the length of the hatching period and clutch size, number hatched, and the Julian Date when the first egg hatched in a clutch. We used ANOVA to make pairwise comparisons between species for the time of day that young fledged. We used a $t$-test to compare fledging ages of video-monitored versus visited nests. We considered $P$-values $<0.10$ to be statistically significant.

\section{Directly Monitored Nests}

We searched for nests of grassland birds from mid-April to late July each year (1998-2000) on J. Clark Salyer National Wildlife Refuge, located in north-central North Dakota. We systematically located nests (between 08:00 and 17:00 CDT) by flushing adult birds using a $25-\mathrm{m}$ weighted rope towed between two observers, with tin cans attached every $0.5 \mathrm{~m}$ (Davis 2003). We also located nests fortuitously and by using behaviors of adult birds (Grant et al. 2005). To estimate age of passerine nests, we candled eggs from each nest during laying or incubation (Lokemoen and Koford 1996) or aged nestlings using voucher photographs of known-age young (e.g., as found in Jongsomjit et al. 2007). We visited passerine nests every 2-5 days until young were near the estimated age of fledging; we then visited nests daily to minimize uncertainty in assigning final nest fates (Grant et al. 2005). Nest visits rarely lasted $>5 \mathrm{sec}$ and most nests were viewed from 1-3 $m$ away. We defined a successful nest as having at least one host young (we omitted nests parasitized by cowbirds) surviving until the potential minimum age of fledging. 
We used behaviors of the parents (e.g., alarm calling, carrying food), presence of young near the nest, nestling age at the previous visit, evidence of nest disturbance, evidence of nestling mortality, and presence of feces or feather scales at the nest to aid in assigning nest fate (Davis 2003, Grant et al. 2005).

From this sample, we selected nests of Clay-colored Sparrows (Spizella pallida), Savannah Sparrows (Passerculus sandwichensis), Chestnutcollared Longspurs (Calcarius ornatus), and Bobolinks (Dolichonyx oryzivorus) that met the following criteria: (1) Nests were visited during hatching; (2) nests were not parasitized by cowbirds; and (3) using the criteria described previously, nests successfully fledged young. For each nest, the first nest visit at which any eggs were hatched was considered the hatch date; the first nest visit at which any young had fledged was considered the fledge date. The difference between these dates was the estimated fledging age for that nest. From the fledging ages for each nest, we determined the mean (and SE), modal, minimum, and maximum fledging ages for each species.

\section{RESULTS}

From video, we documented the time of hatch for 279 eggs of nine species at 84 unparasitized nests. There were no discernible differences among species (Fig. 4.1). The peak hour of hatch was 06:00 (CDT), with more eggs hatching between 05:30 and 06:30 than in any other 1-hr period (Fig. 4.1). This peak may result in part because most hatching events were defined by parent's removal of the eggshell and no eggshells were removed during the night. Given this caveat, individual hatch times ranged from $04: 45$ to $21: 50$, and $38 \%$ of all eggs hatched by 08:00.

In ten parasitized nests, hatch times for 18 host eggs (three species) covered a range similar to hatch times for eggs from unparasitized nests (Fig. 4.1). Nine cowbird eggs hatched from seven parasitized nests; six of the nine cowbird eggs hatched before 08:00, and one hatched at 04:33. Six cowbird eggs from four nests hatched before any host eggs in their respective nests (from $<1 \mathrm{hr}$ to 1 day earlier). No cowbird eggs hatched from three parasitized nests.

The length of the hatching period (excluding nests with only one egg hatching) was calculated for 63 unparasitized nests of seven species and for nine parasitized nests of three species (Table 4.1). Length of the hatching period varied greatly among nests; most clutches $(n=49)$ required $>1$ day to hatch. In our small sample, the presence of cowbird eggs had little or no effect on the range of values for a species.

When all unparasitized nests were pooled, the length of the hatching period was positively correlated with the number of eggs hatched $(r=0.457$,

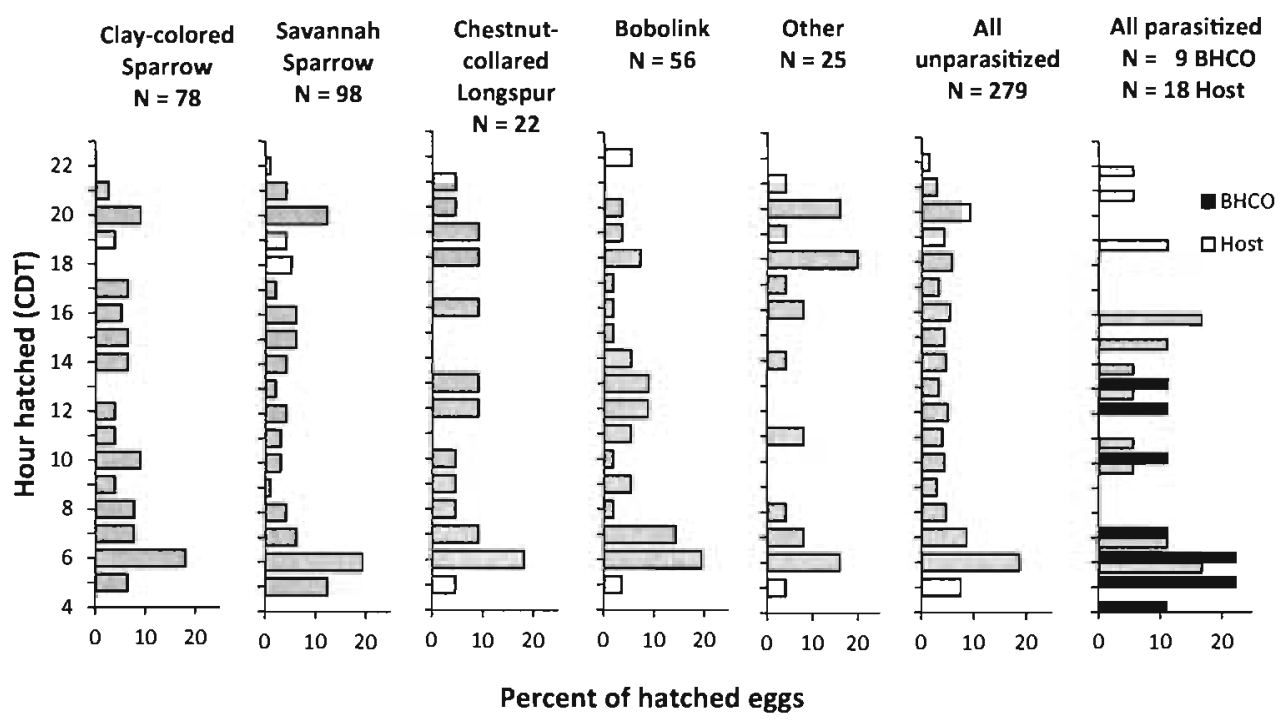

Figure 4.1. Time of day (to the nearest hour) (CDT) that grassland passerine eggs hatched in video-monitored nests in North Dakota, 1996-1999, and Minnesota, 2000-2001. Percentages are based on all hatched eggs for a given species or subgroup. "Other" species include Baird's Sparrow ( $n=3$ eggs), Common Yellowthroat (Geothlypis trichas, $n=3$ eggs), Le Conte's Sparrow (Ammodramus leconteii, $n=3$ eggs), Vesper Sparrow $(n=10$ eggs), and Western Meadowlark ( $n=6$ eggs). Eggs from parasitized nests are only included in the last column (far right). 
TABLE 4.1

Length of hatching period for grassland passerines from 72 video-monitored nests in North Dakota, 1996-1999,

and Minnesota, 2000-2001.

\begin{tabular}{|c|c|c|c|c|c|c|}
\hline \multirow[b]{2}{*}{ Species } & \multirow[b]{2}{*}{ Number of nests } & \multicolumn{5}{|c|}{ Length of hatching period (number eggs hatched) } \\
\hline & & Median & Minimum & Maximum & Mean & $\mathrm{SE}$ \\
\hline \multicolumn{7}{|l|}{ Unparasitized Nests } \\
\hline $\begin{array}{l}\text { Clay-colored Sparrow } \\
\text { (Spizella pallida) }\end{array}$ & 20 & $19: 53 \quad(4)$ & $5: 03 \quad(3)$ & $43: 45 \quad(4)$ & $21: 22 \quad(3.6)$ & $2: 22$ \\
\hline $\begin{array}{l}\text { Vesper Sparrow } \\
\text { (Pooecetes gramineus) }\end{array}$ & 3 & $15: 04 \quad(3)$ & $0: 23$ & $15: 41 \quad(3)$ & $10: 22$ & $5: 00$ \\
\hline $\begin{array}{l}\text { Savannah Sparrow } \\
\text { (Passerculus sandwichensis) }\end{array}$ & 21 & $17: 20 \quad(4)$ & $0: 04 \quad(2)$ & $43: 53 \quad(3)$ & $17: 32(4.1)$ & $2: 29$ \\
\hline $\begin{array}{l}\text { Baird's Sparrow } \\
\text { (Ammodramus bairdii) }\end{array}$ & 1 & $22: 28$ & & & $22: 28$ & \\
\hline $\begin{array}{l}\text { Chestnut-collared Longspur } \\
\text { (Calcarius ornatus) }\end{array}$ & 5 & $29: 44 \quad(4)$ & $25: 14 \quad(5)$ & $55: 02 \quad(5)$ & $34: 16 \quad(4.4)$ & $5: 21$ \\
\hline $\begin{array}{l}\text { Bobolink } \\
\text { (Dolichonyx oryzivorus) }\end{array}$ & 12 & $29: 30 \quad(5)$ & $4: 07 \quad(4)$ & $46: 06 \quad(6)$ & $27: 48 \quad(4.7)$ & $3: 38$ \\
\hline $\begin{array}{l}\text { Western Meadowlark } \\
\text { (Sturnella neglecta) }\end{array}$ & 1 & $68: 25 \quad(6)$ & & & $68: 25 \quad(6)$ & \\
\hline \multicolumn{7}{|l|}{ Parasitized Nests } \\
\hline Clay-colored Sparrow & 7 & $18: 15 \quad(2,1)$ & $3: 50 \quad(2,2)$ & $37: 54 \quad(3,1)$ & $20: 09 \quad(1.9,1.0)$ & $5: 04$ \\
\hline Bobolink & 1 & $8: 53 \quad(4,0)$ & & & $8: 53 \quad(4,0)$ & \\
\hline $\begin{array}{l}\text { Red-winged Blackbird } \\
\text { (Agelaius phoeniceus) }\end{array}$ & 1 & $28: 39 \quad(1,1)$ & & & $28: 39 \quad(1,1)$ & \\
\hline
\end{tabular}

NOTES: Length of hatching period is the length of time (hr:min) from first egg hatching to last egg hatching. In the median, minimum, and maximum columns, parenthetical values are the number of eggs that hatched in single nests; in the mean column, the parenthetical values are the average number of hatched eggs for nests of that species. Parenthetical numbers for parasitized nests are the number of host eggs that hatched, followed by the number of cowbird eggs that hatched. Parasitized nests contained eggs of Brown-headed Cowbirds (Molothrus ater); unparasitized nests did not. 


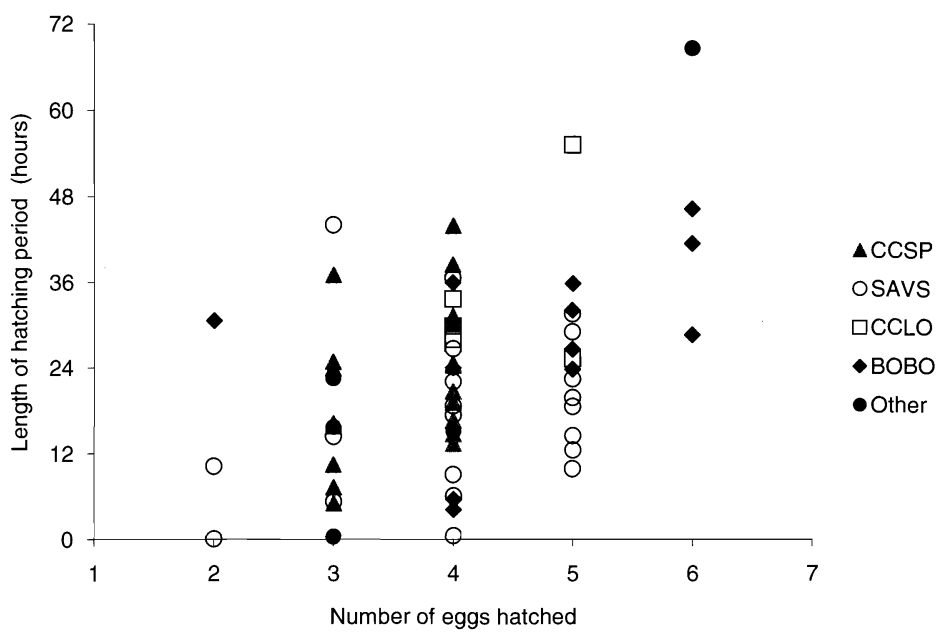

Figure 4.2. Relation between the length of the hatching period and the number of eggs hatched at individual grasslandpasserine nests video-monitored in North Dakota, 1996-1999, and Minnesota, 2000-2001. Alpha codes represent Clay-colored Sparrow (CCSP), Savannah Sparrow (SAVS), Chestnut-collared Longspur (CCLO), and Bobolink (BOBO). "Other" species include Baird's Sparrow (1 nest), Vesper Sparrow (3 nests), and Western Meadowlark (1 nest).

$P=0.0002, n=63$; Fig. 4.2) and to a lesser extent with Julian Date $(r=0.234, P=0.066, n=63)$. These overall patterns may have been driven primarily by within-species relationships of species that dominated the data set, such as Clay-colored Sparrows for number of eggs hatched $(r=0.403$, $P=0.078, n=20$ ) and Savannah Sparrows for Julian Date $(r=0.442, P=0.045, n=21)$.

For unparasitized nests, we found a statistically significant negative correlation between the number of eggs hatched and Julian Date $(r=$ $-0.248, P=0.050, n=63)$ but not between clutch size and Julian Date $(r=-0.200, P=0.12$, $n=63$ ). We obtained similar results when just Savannah Sparrow nests were considered (Julian Date with number hatched: $r=-0.405, P=0.069$; Julian Date with clutch size: $r=0.089, P=0.70$, $n=21$ ), but found the opposite for Bobolink nests (Julian Date with number hatched: $r=-0.475$, $P=0.12$; Julian Date with clutch size: $r=-0.713$, $P=0.009 ; n=12$ ). For Clay-colored Sparrows, we found no correlation between Julian Date and either variable (number hatched: $r=-0.246, P=$ 0.30 ; clutch size: $r=-0.214, P=0.36 ; n=20$ ).

Time of fledging was recorded for 213 nestlings of nine species (including two cowbird nestlings from two nests) and usually occurred during 06:30-12:30 CDT (74\% of fledgings; Fig. 4.3). One Clay-colored Sparrow nestling inexplicably left the nest at 03:48. Fledging time varied among the three species with the largest samples $\left(F_{2,57}=\right.$
5.47, $P=0.005)$. Clay-colored Sparrows fledged earlier in the day $(\bar{x} \pm$ SE: 09:30 $\pm 32 \mathrm{~min})$ than Savannah Sparrows $(12: 05 \pm 35 \mathrm{~min}, P=0.002)$ or Bobolinks (11:26 $\pm 50 \mathrm{~min}, P=0.055)$.

Length of the fledging period (excluding nests with only one fledgling, with cowbird young, or with early departures attributed to disturbance) was recorded for seven species at 53 nests (Table 4.2). In contrast to the protracted hatching period, all nestlings within a nest usually fledged on the same day, often (45\%) within $<2 \mathrm{hr}$. At 16 nests without cowbird nestlings, fledging took 2 days to complete, and at one nest (Savannah Sparrow), fledging took 3 days. At two nests with cowbird nestlings, the fledging period was 3 days. One cowbird remained in each nest 2 days after the first host young [Grasshopper Sparrow (Ammodramus savannarum), Clay-colored Sparrow] fledged; these were the only natural cowbird fledgings on videotape. At the third nest with a cowbird nestling, the nest tipped over $2 \mathrm{hr}$ after the only host nestling fledged (Clay-colored Sparrow).

Age at fledging determined from video was generally similar to that determined from nest visits (Table 4.3). Minimum fledging ages for each species were about 1-2 days younger for visited nests; however, ranges were also greater, and maximum fledging ages were up to 2 days older for visited nests, presumably reflecting larger samples of visited nests than video-monitored nests. Mean values of fledging age for the two groups 

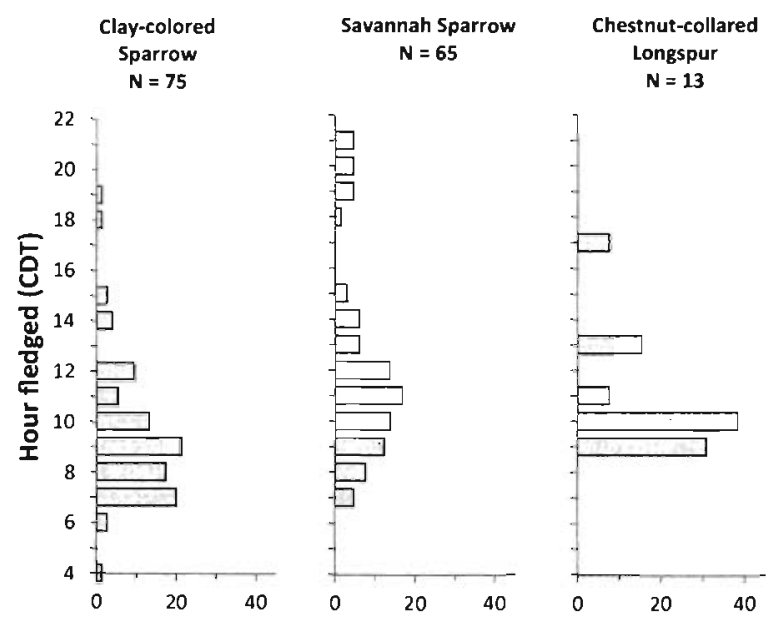

Bobolink

Other

$N=13$

$\mathbf{N}=\mathbf{4 0}$

$\mathbf{N}=\mathbf{2 0}$
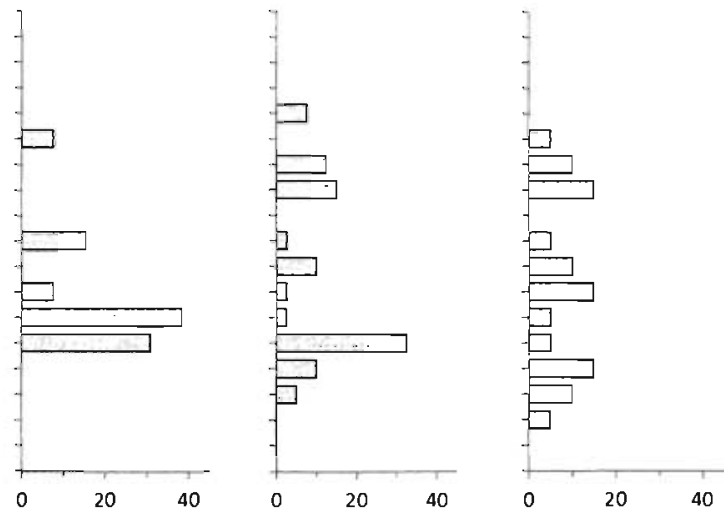

Percent of fledged young

Figure 4.3. Time of day (to the nearest hour) (CDT) that 213 grassland passerines fledged from video-monitored nests in North Dakota, 1996-1999, and Minnesota, 2000-2001. "Other" species include Baird's Sparrow ( $n=3$ young), Grasshopper Sparrow ( $n=7$ young), Le Conte's Sparrow ( $n=2$ young), Vesper Sparrow ( $n=6$ young), and Brown-headed Cowbird ( $n=2$ young). One Clay-colored Sparrow and two Grasshopper Sparrows fledged from nests with Brown-headed Cowbird young.

differed for Clay-colored Sparrows $\left(t_{181}=-1.92\right.$, $P=0.056)$, the only species for which a statistical test seemed warranted. The most common fledging age (mode) of Clay-colored Sparrows was 1 day younger for visited nests than for video-monitored nests.

Average fledging ages determined from video fell within ranges reported in the literature, but expanded the range of ages higher for Clay-colored Sparrows and lower for Bobolinks (Table 4.3). The oldest mean fledging age at a Clay-colored Sparrow nest was 1.3 days older than the maximum reported by Knapton (1994), but our modal values matched. The range reported for Savannah Sparrows was considerably greater than for our 11 videotaped nests, although our mean age was similar to those reported for some study sites in Canada (Wheelwright and Rising 2008). Some Bobolinks on video fledged 1-2 days sooner than previously reported.

With video, we documented forced fledging at 15 nests as a result of predators, people visiting the nest to adjust the camera, ants in the nest, or the nest tipping over (Table 4.4). At six of the 15 nests, ages of force-fledged young were within the range of natural fledging ages recorded on videotape for that species; at five nests, young left 1 day earlier than the minimum age recorded; and at three nests young left 2 days earlier. A cowbird forced from a Song Sparrow (Melospiza melodia) nest was 3 days younger than two cowbirds that fledged naturally.

\section{DISCUSSION}

Most grassland passerine species nest on or near the ground. The primary exception in our study was the Clay-colored Sparrow, which typically nests above the ground in small shrubs (Knapton 1994). For the Clay-colored Sparrow nests that we monitored with cameras ( $n=75)$, nest height averaged $24 \mathrm{~cm}$ and ranged up to $66 \mathrm{~cm}$. With this elevation, Clay-colored Sparrow young that are prematurely displaced may be less likely to return to nests than young of ground-nesting species. We found that the modal fledging age of Clay-colored Sparrows at visited nests was 1 day younger than at video-monitored nests. It is unclear how much 1 less day in the nest would affect survivability of young, although fledglings are likely to be most vulnerable during their first few days outside the nest. Suedkamp Wells (2005) found that the cumulative probability of survival of Dickcissel (Spiza americana) and Eastern Meadowlark (Sturnella magna) fledglings declined rapidly during the first 4 days after fledging.

Similarly, how a 1-day difference in exposure days (e.g., for Clay-colored Sparrows) might affect the classification of nest fates and calculation of survival rates is difficult to predict. Testing for 
TABLE 4.2

Length offledging period for 53 video-monitored nests of grassland passerines in North Dakota, 1996-1999, and Minnesota, 2000-2001.

\begin{tabular}{|c|c|c|c|c|c|c|c|c|}
\hline \multirow{3}{*}{$\frac{\text { Species }}{\text { Clay-colored Sparrow }}$} & \multirow{3}{*}{$\frac{\text { Number of nests }}{20}$} & \multicolumn{7}{|c|}{ Length of fledging period (number fledged) } \\
\hline & & \multicolumn{2}{|c|}{ Median } & Minimum & Maximum & \multicolumn{2}{|c|}{ Mean } & \multirow{2}{*}{$\begin{array}{l}\mathrm{SE} \\
2: 08\end{array}$} \\
\hline & & $3: 21$ & (3) & $0: 00 \quad(2)$ & $25: 56$ & $8: 24$ & $(3.4)$ & \\
\hline Vesper Sparrow & 2 & 12:07 & (3) & $0: 29 \quad(2)$ & $23: 46 \quad(4)$ & 12:07 & (3) & $11: 38$ \\
\hline Savannah Sparrow & 16 & $3: 19$ & $(3.5)$ & $0: 16 \quad(2)$ & $37: 29 \quad(5)$ & $7: 38$ & $(3.6)$ & $2: 45$ \\
\hline $\begin{array}{l}\text { Grasshopper Sparrow } \\
\text { (Ammodramus savannarum) }\end{array}$ & 1 & $20: 43$ & (4) & & & $20: 43$ & (4) & \\
\hline Baird's Sparrow & 1 & $0: 52$ & (3) & & & $0: 52$ & (3) & \\
\hline Chestnut-collared Longspur & 3 & $19: 23$ & (4) & $4: 14 \quad(4)$ & $22: 59 \quad(4)$ & $15: 32$ & $(4.3)$ & $5: 44$ \\
\hline Bobolink & 10 & 2:08 & (4) & $0: 02 \quad$ (4) & $22: 48 \quad(2)$ & $7: 25$ & (3.9) & $2: 51$ \\
\hline
\end{tabular}

NOTE: Length of fledging period is the length of time (hr:min) from first young departing nest to last young departing nest, excluding nests with only one fledgling, with Brown-headed Cowbird young, or with early departures attributed to disturbance (i.e., forced fledging). In the median, minimum, and maximum columns, parenthetical values are the number of fledged young from single nests; in the mean column, the parenthetical values are the average number of fledged young for nests of that species. 
TABLE 4.3

Fledging ages of grassland passerines determined from video-monitoring (V) and directly monitoring (D) nests, compared to typical ages (and ranges) previously published.

\begin{tabular}{|c|c|c|c|c|c|c|c|c|}
\hline Species & Method & $\begin{array}{l}\text { Number } \\
\text { of nests }\end{array}$ & Mode & Mean & SE & Minimum & Maximum & Published \\
\hline \multirow[t]{2}{*}{ Clay-colored Sparrow } & $\mathrm{V}$ & 13 & 9 & 8.7 & 0.21 & 6.9 & 10.3 & $9(7-9)$ \\
\hline & $\mathrm{D}$ & 170 & 8 & 8.2 & 0.07 & 6 & 11 & \\
\hline \multirow[t]{2}{*}{ Savannah Sparrow } & $\mathrm{V}$ & 11 & 9 & 9.5 & 0.16 & 9.0 & 10.7 & $(7-13)$ \\
\hline & $\mathrm{D}$ & 103 & 9 & 9.2 & 0.09 & 7 & 11 & \\
\hline \multirow[t]{2}{*}{ Chestnut-collared Longspur } & V & 2 & - & 9.9 & 0.33 & 9.6 & 10.3 & $10(9-14)$ \\
\hline & $\mathrm{D}$ & 4 & 11 & 10.3 & 0.48 & 9 & 11 & \\
\hline \multirow[t]{2}{*}{ Bobolink } & V & 8 & 10 & 9.7 & 0.20 & 8.7 & 10.4 & $(10-11)$ \\
\hline & D & 21 & 10 & 10.0 & 0.25 & 8 & 12 & \\
\hline
\end{tabular}

NOTES: Fledging ages are given in days. Nests were monitored using video in North Dakota, 1996-1999, and Minnesota, 2000-2001. Nests were directly monitored (i.e., with nest visits) at J. Clark Salyer National Wildlife Refuge, North Dakota, 1998-2000. For Method, V = data from video-monitored nests (excluding nests with force-fledged young); D = data from direct observations during nest checks. To calculate the mode for video-monitored nests, we first calculated the modal fledging age for each nest (i.e., the modal fledge date for young in that nest minus the modal hatch date for eggs in that nest). The mode for the species was the most frequently occurring modal fledging age among the nests of that species. Note that no mode could be calculated for Chestnut-collared Longspurs because there were only two nests in this sample and their modal fledging ages were 10 and 11 days. To calculate the mean for video-monitored nests, we first calculated a mean fledging age for each nest (i.e., the mean fledge date for young in that nest minus the mean hatch date for eggs in that nest). The mean and standard error (SE) for each species were then calculated from the mean fledging ages for individual nests of that species. The minimum and maximum values for video-monitored nests represent the lowest and highest mean fledging ages among nests of that species. For each directly monitored nest, fledging age was determined by subtracting the date of the first nest visit when a nestling had fledged from the date of the first nest visit when an egg had hatched. The mode for each species was the most frequently occurring fledging age among the nests for that species. The mean and SE for each species were calculated from the fledging ages estimated for nests of that species. The minimum and maximum values for directly monitored nests represent the lowest and highest fledging ages estimated for nests of that species. Published values of fledging ages were taken from Birds of North America species accounts (Poole 2005). For Bobolink, a wider range of 10-14 days is given in Ehrlich et al. (1988) and Baicich and Harrison (1997). 
TABLE 4.4

Age (in days) of grassland passerine nestlings when force fledged from video-monitored nests in North Dakota, 1996-1999, and Minnesota, $2000-2001$.

\begin{tabular}{|c|c|c|c|c|}
\hline Species & Agent & Age forced & Number of nestlings & Comments \\
\hline \multirow[t]{8}{*}{ Clay-colored Sparrow } & $\begin{array}{l}\text { Thirteen-lined ground squirrel } \\
\text { (Ictidomys tridecemlineatus) }\end{array}$ & (6) & 2 & A third nestling was depredated at the nest. \\
\hline & Thirteen-lined ground squirrel & (7) & 2 & A third nestling was depredated at the nest. \\
\hline & Thirteen-lined ground squirrel & (7) & 2 & A third nestling was depredated at the nest. \\
\hline & Observer & 8 & 3 & Entire brood forced. \\
\hline & Observer & 7,8 & 2 & $\begin{array}{l}\text { One nestling on each of two consecutive days; } \\
\text { one fledged naturally before second visit. }\end{array}$ \\
\hline & Ants & (6) & 2 & $\begin{array}{l}\text { Nestlings left } 1.5 \text { and } 4 \mathrm{hr} \text { after camera setup; } \\
\text { also may have been overheating in the sun. }\end{array}$ \\
\hline & $\begin{array}{l}\text { Plains gartersnake } \\
\text { (Thamnophis radix) }\end{array}$ & 8 & 1 & Two nestlings remained in nest. \\
\hline & Mouse or vole & 8 & 4 & Entire brood; none depredated at nest. \\
\hline \multirow[t]{3}{*}{ Savannah Sparrow } & $\begin{array}{l}\text { White-tailed deer } \\
\text { (Odocoileus virginianus) }\end{array}$ & (7) & 1 & $\begin{array}{l}\text { Other three were depredated; fledgling was } \\
\text { depredated outside nest on videotape. }\end{array}$ \\
\hline & Observer & $(10)$ & 2 & $\begin{array}{l}\text { One fledged naturally before and two fledged } \\
\text { naturally after observer visit. }\end{array}$ \\
\hline & Plains gartersnake & (7) & 5 & $\begin{array}{l}\text { One forced and chased by snake; others were in } \\
\text { and out of nest but all left within } 1.5 \mathrm{hr} \text {. }\end{array}$ \\
\hline Grasshopper Sparrow & White-tailed deer & (8) & 1 & $\begin{array}{l}\text { One fledged naturally before deer visit; two } \\
\text { others were depredated by deer. }\end{array}$ \\
\hline Song Sparrow & Thirteen-lined ground squirrel & (7) & 2 & $\begin{array}{l}\text { One host and one cowbird forced; one host and } \\
\text { one cowbird depredated. }\end{array}$ \\
\hline Bobolink & Thirteen-lined ground squirrel & 9 & 1 & $\begin{array}{l}\text { One was depredated by ground squirrel at time } \\
\text { of forced fledging. }\end{array}$ \\
\hline Brown-headed Cowbird & Nest tipped over & 9 & 1 & $\begin{array}{l}\text { One host (Clay-colored Sparrow) fledged natu- } \\
\text { rally } 1 \mathrm{hr} \text { earlier. }\end{array}$ \\
\hline
\end{tabular}

NOTES: Young were considered "force fledged" if their departure from the nest coincided with the visit of a predator or an observer to the nest or the nest tipping over. Ages in parentheses are estimates: camera was placed at nest after hatching. Common and scientific names of mammal species follow Wilson and Reeder (2005) and those of snake species follow Crother (2008). 
effects of nest visits on nesting success has led to varied results (Götmark 1992, Johnson 2007), in part due to inadequate statistical power to detect small effects (Rotella et al. 2000). As Rotella et al. (2000) noted, ignoring small effects can have important consequences because small changes in daily survival rate yield large changes in estimated nesting success (i.e., period nest survival).

Most mean and modal values for fledging age determined from video-monitored nests were similar to those determined by nest visits. This similarity might be attributed to how nests were visited in our study at J. Clark Salyer National Wildlife Refuge. Because visits rarely lasted $>5 \mathrm{~s}$ and because most nests were viewed from 1-3 m away, the risk of inducing premature fledging was likely reduced. However, Clay-colored Sparrow nests routinely required the closest inspection by observers, primarily because these nests often were completely obscured by a canopy of low shrub. Researchers who spend more time at nests or approach more closely may be more likely to influence fledging. For example, at one of our video-monitored Clay-colored Sparrow nests, the three 8-day-old nestlings remained still while a researcher adjusted the camera, but video showed that they all left the nest $<1 \mathrm{~min}$ after the person departed. Without video, we would not have known that the visit had affected the fledging time. Vickery (1996) noted that disturbance at Grasshopper Sparrow nests "after day 7 or 8 can induce premature nestling departure and mortality." We echo Cole's (1910) advice from a century ago that researchers who handle older nestlings (e.g., to measure or band) need to be aware of their possible impacts. Advice on appropriate ages for banding that minimizes the risk of "jumping" is available for some species (Jongsomjit et al. 2007). Note that some authors (e.g., Jongsomjit et al. 2007, Wheelright and Rising 2008) consider hatch day to be nestling "day 1." When aging nestlings, however, we and many others [e.g., Carey et al. 1994, Greenlaw and Rising 1994, Knapton 1994 (confirmed by pers. comm.), Hill and Gould 1997, Shane 2000] consider hatch day to be "day 0."

Average fledging ages derived from both videomonitored and directly monitored nests fell within the range of fledging ages previously published; however, both data sets expanded the published ranges higher for Clay-colored Sparrows and lower for Bobolinks. These broad ranges highlight the difficulty of choosing a single value for a species when assessing nest fates and estimating survival (e.g., Mayfield 1961, Shaffer 2004). Because average ages obtained from video generally corroborated those obtained from careful nest visits, direct monitoring with nest visits (where strict protocols are observed) provides a reasonable method to obtain information for survival estimates and allows more nests to be monitored when resources are limited.

The short brood-rearing period of many grassland passerines may be an adaptation to escape late-stage predation (Grant et al. 2005). This follows from the general thesis that species with more exposed nest sites (e.g., ground-nesters) have more rapidly developing young "to reduce the time of greatest vulnerability to predators" (Winkler 2004:8.117). Growth rates within species also may affect vulnerability; for Meadow Pipits (Anthus pratensis), an open-nesting species, Halupka (1998) found the probability that a predator attack would result in destruction of the entire brood decreased with increasing growth rate. Frei et al. (2010) noted that young Bobolinks fledge well below adult mass; however, like Eastern Meadowlarks (Sturnella magna) and Savannah Sparrows, their tarsi are nearly adult length. Frei et al. (2010) suggest that accelerated development of tarsi may be an adaptation to enable young to run from the nest if disturbed prior to fledging. In a video study of Grasshopper Sparrows, Adler (2010) suggested that parents tended to reduce provisioning during the last days of the brood period, possibly to induce young to fledge. Although it seems intuitive that young in ground nests would typically be more vulnerable to predators, it is difficult to find direct evidence that brood dispersal decreases predation risk (McLaughlin and Montgomerie 1989).

Our video showed that most young fledged in daylight before mid-day. Similar patterns have been documented for some cavity-nesting species of wrens and tits (Lemel 1989, Nilsson 1990, Verhulst and Hut 1996, Johnson et al. 2004). This pattern may provide a selective advantage by giving fledglings more time to become familiar with their surroundings and to find relatively safe roost sites before dark (Johnson et al. 2004).

Our video showed that the fledging period was considerably shorter than the hatching period for most species. Part of this may reflect attrition between hatching and fledging if, on average, more eggs hatched from nests than young 
fledged. In our data, however, the mean number hatched was only slightly greater than the mean number fledged; this difference was small compared to the difference between the lengths of the hatching and fledging periods. Considering the three species with the most samples in our data set, median hatching periods for Clay-colored and Savannah Sparrows were about 5-6 times longer than that of their respective fledging periods, and for Bobolinks the median hatching period was nearly 14 times longer than the fledging period.

We documented relatively synchronous fledging, which appears to be common among passerines. Even young of the House Wren (Troglodytes aedon), a cavity-nesting species with a marked age/size hierarchy within broods, generally fledge on the same day (Johnson et al. 2004). For House Wrens, Johnson et al. (2004) found no evidence that fledging was triggered by changes in parental behavior or feeding rates. For 18 of 19 broods of Marsh Tits (Parus palustris), Nilsson (1990) found that the last nestling fledged within $5 \mathrm{hr}$ of the first. He found no evidence of parental manipulation, although the last young in nests were fed less per nestling after part of the brood had fledged. This may result if parents attempt to satiate fledglings first in an effort to quiet them quickly, thus reducing the chances of attracting predators to the area around the nest site (Lemel 1989).

Our video revealed that Brown-headed Cowbird eggs typically hatched before the host eggs in parasitized nests. Nice (1953) noted that John James Audubon had written in 1831 that the cowbird's egg hatched first, but she questioned published accounts about the length of the cowbird's incubation period. Because species of parasitic cowbirds are thought to have short incubation periods relative to their egg mass, some researchers have explored various mechanisms that might account for this (e.g., Kattan 1995, McMaster and Sealy 1998). Berger (1951) suggested that the cowbird's custom of removing a host egg increased the chances that its own egg would hatch first. In any case, hatching before their host counterparts is assumed to give young cowbirds a competitive edge. Researchers have used video to examine how the presence of cowbird nestlings affects begging behavior, provisioning rates, and survival of host young (e.g., Pappas et al. 2010, Rivers et al. 2010).

We provided several examples of the types of information that can be obtained on hatching and fledging chronology by using video surveillance at nests. Video surveillance provided new information that would have been difficult or impossible to obtain by other methods. In addition, by comparing videoed and visited nests, we showed that carefully conducted nest visits generally can provide reliable data for deriving survival estimates. Our video findings also served another purpose: supplying evidence for statements already in the literature, as recommended by Margaret Morse Nice (1953) over half a century ago.

\section{ACKNOWLEDGMENTS}

We thank our research collaborators, D. H. Johnson, S. L. Jones, E. M. Madden, J. A. Shaffer, and M. Winter. We also thank all the field technicians who helped collect the data used in this paper. D. A. Buhl and T. L. Shaffer provided help with statistical analyses; L. D. Igl suggested numerous references. Camera systems were built by J. Christensen, R. Fuhrman, and D. K. Garcelon. L. D. Igl, G. Ritchison, and F. R. Thompson III, provided helpful reviews of earlier versions of this paper. The findings and conclusions in this article are those of the authors and do not necessarily represent the views of the U.S. Fish and Wildlife Service. The use of trade, product, or firm names in this article is for descriptive purposes only and does not imply endorsement by the U.S. Government. Financial support was provided by Northern Prairie Wildlife Research Center of the U.S. Geological Survey, and by Regions 6 and 3 Nongame Bird Conservation Programs and J. Clark Salyer National Wildlife Refuge of the U.S. Fish and Wildlife Service.

\section{LITERATURE CITED}

Adler, J. 2010. Provisioning behavior of male and female Grasshopper Sparrows. M.S. thesis, Eastern Kentucky University, Richmond, KY.

Baicich, P. J., and C. J. O. Harrison. 1997. A guide to the nests, eggs, and nestlings of North American birds. Academic Press, San Diego, CA.

Berger, A. J. 1951. The cowbird and certain host species in Michigan. Wilson Bulletin 63:26-34.

Carey, M., D. E. Burhans, and D. A. Nelson. 1994. Field Sparrow (Spizella pusilla). Birds of North America No. 103, Academy of Natural Sciences, Philadelphia, PA.

Cole, L. J. 1910. The tagging of wild birds: report of progress in 1909. Auk 27:153-168.

Crother, B. I. (editor). 2008. Scientific and standard English names of amphibians and reptiles of North America north of Mexico. Herpetological Circular No. 37. Society for the Study of Amphibians and Reptiles, Salt Lake City, UT. 
Davis, S. K. 2003. Nesting ecology of mixed-grass prairie songbirds in southern Saskatchewan. Wilson Bulletin 115:119-130.

Ehrlich, P. R., D. S. Dobkin, and D. Wheye. 1988. The birder's handbook. Simon and Schuster, New York, NY.

Eikenaar, C., M. L. Berg, and J. Komdeur. 2003. Experimental evidence for the influence of food availability on incubation attendance and hatching asynchrony in the Australian Reed Warbler Acrocephalus australis. Journal of Avian Biology 34:419-427.

Frei, B., D. M. Bird, and R. D. Titman. 2010. Bobolink egg mass variability and nestling growth patterns. Wilson Journal of Ornithology 122:432-438.

Götmark, F. 1992. The effects of investigator disturbance on nesting birds. Current Ornithology 9:63-104.

Grant, T. A., T. L. Shaffer, E. M. Madden, and P. J. Pietz. 2005. Time-specific variation in passerine nest survival: new insights into old questions. Auk 122:661-672.

Greenlaw, J. S., and J. D. Rising. 1994. Sharp-tailed Sparrow (Ammodramus caudacutus). Birds of North America No. 112, Academy of Natural Sciences, Philadelphia, PA.

Halupka, K. 1998. Partial nest predation in an altricial bird selects for the accelerated development of young. Journal of Avian Biology 29:129-133.

Hill, D. P., and L. K. Gould. 1997. Chestnut-collared Longspur (Calcarius ornatus). Birds of North America No. 288, Academy of Natural Sciences, Philadelphia, PA.

Johnson, D. H. 2007. Methods of estimating nest success: an historical tour. Studies in Avian Biology 34:1-12.

Johnson, L. S., R. L. Rauch, and S. N. Dellone. 2004. The process and causes of fledging in a cavitynesting passerine bird, the House Wren (Troglodytes aedon). Ethology 110:693-705.

Jongsomjit, D., S. L. Jones, T. Gardali, G. R. Geupel, and P. J. Gouse. 2007. A guide to nestling development and aging in altricial passerines. Biological Technical Publication FWS/BTP-R6008-2007. U.S. Department of Interior, Fish and Wildlife Service, Washington, DC.

Kattan, G. H. 1995. Mechanisms of short incubation period in brood-parasitic cowbirds. Auk 112:335-342.

Knapton, R. W. 1994. Clay-colored Sparrow (Spizella pallida). Birds of North America No. 120, Academy of Natural Sciences, Philadelphia, PA.

Lemel, J. 1989. Body-mass dependent fledging order in the Great Tit. Auk 106:490-492.

Lokemoen, J. T., and R. R. Koford. 1996. Using candlers to determine the incubation stage of passerine eggs. Journal of Field Ornithology 67:660-668.
Martin, T. E., C. R. Paine, C. J. Conway, W. M. Hochachka, P. Allen, and W. Jenkins. 1997. BBIRD field protocol. Montana Cooperative Wildlife Research Unit, University of Montana, Missoula, MT. <http://www.umt.edu/bbird/docs/BBIRDPROT.pdf> (22 July 2010).

Mayfield, H. 1961. Nesting success calculated from exposure. Wilson Bulletin 73:255-261.

McLaughlin, R. L., and R. D. Montgomerie. 1989. Early nest departure does not improve the survival of Lapland Longspur chicks. Auk 106:738-741.

McMaster, D. G., and S. G. Sealy. 1998. Short incubation periods of Brown-headed Cowbirds: how do cowbird eggs hatch before Yellow Warbler eggs? Condor 100:102-111.

Nice, M. M. 1953. The question of ten-day incubation periods. Wilson Bulletin 65:81-93.

Nilsson, J.-A. 1990. What determines the timing and order of nest-leaving in the Marsh Tit (Parus palustris)? Pp. 369-379 in J. Blondel, A. Gosler, J. -D. Lebreton, and R. McCleery (editors), Population biology of passerine birds: an integrated approach. Springer-Verlag, Berlin, Germany.

Pappas, S., T. J. Benson, and J. C. Bednarz. 2010. Effects of Brown-headed Cowbird parasitism on provisioning rates of Swainson's Warblers. Wilson Journal of Ornithology 122:75-81.

Pietz, P. J., and D. A. Granfors. 2000. Identifying predators and fates of grassland passerine nests using miniature video cameras. Journal of Wildlife Management 64:71-87.

Poole, A. (editor). 2005. The Birds of North America online. Cornell Laboratory of Ornithology, Ithaca, NY. < http://bna.birds.cornell.edu/BNA > (10 June 2008).

Rivers, J. W., T. M. Loughin, and S. I. Rothstein. 2010. Brown-headed Cowbird nestlings influence nestmate begging, but not parental feeding, in hosts of three distinct sizes. Animal Behaviour 79:107-116.

Rotella, J. J., M. L. Taper, and A. J. Hansen. 2000. Correcting nesting-success estimates for observer effects: maximum-likelihood estimates of daily survival rates with reduced bias. Auk 117:92-109.

Shaffer, T. L. 2004. A unified approach to analyzing nest success. Auk 121:526-540.

Shane, T. G. 2000. Lark Bunting (Calamospiza melanocorys). Birds of North America No. 542, Academy of Natural Sciences, Philadelphia, PA.

Smith, K. G. 2010. 100 years ago in the American Ornithologists' Union. Auk 127:469-470.

Suedkamp Wells, K. M. 2005. Resource selection, movement patterns, and survival of post-fledging grassland birds in Missouri. Ph.D. dissertation, University of Missouri, Columbia, MO. 
Thompson, F. R., III, W. Dijak, and D. E. Burhans. 1999. Video identification of predators at songbird nests in old fields. Auk 116:259-264.

Verhulst, S., and R. A. Hut. 1996. Post-fledging care, multiple breeding and the costs of reproduction in the Great Tit. Animal Behaviour 51:957-966.

Vickery, P. D. 1996. Grasshopper Sparrow (Ammodramus savannarum). Birds of North America No. 239, Academy of Natural Sciences, Philadelphia, PA.

Wheelwright, N. T., and J. D. Rising. 2008. Savannah Sparrow (Passerculus sandwichensis). In A. Poole (editor), The Birds of North America online.
Cornell Laboratory of Ornithology, Ithaca, NY. < http:// bna.birds.cornell.edu/bna/species/045> (20 August 2010).

Wilson, D. E., and D. M. Reeder (editors). 2005. Mammal species of the world: a taxonomic and geographic reference, 3rd ed. Johns Hopkins University Press, Baltimore, MD.

Winkler, D. W. 2004. Nests, eggs, and young: breeding biology of birds. Pp. 8.1-8.152 in S. Podulka, R. W. Rohrbaugh, Jr., and R. Bonney (editors), Handbook of bird biology. Second edition. Cornell Laboratory of Ornithology, Ithaca, NY. 